\title{
Effective Environmental Education through Half-Day Teaching Programmes Outside School
}

\author{
Jürgen Drissner, ${ }^{1}$ Hans-Martin Haase, ${ }^{2}$ Annette Rinderknecht, ${ }^{1}$ and Katrin Hille ${ }^{3}$ \\ ${ }^{1}$ Botanical Garden, University of Ulm, 89081 Ulm, Germany \\ ${ }^{2}$ University of Education, Oberbettringer Straße 200, 73525 Schwäbisch Gmünd, Germany \\ ${ }^{3}$ Transfer Center for Neuroscience and Learning, University of Ulm, Beim Alten Fritz 2, 89075 Ulm, Germany \\ Correspondence should be addressed to Jürgen Drissner; juergen.drissner@uni-ulm.de
}

Received 7 February 2013; Accepted 19 May 2013

Academic Editors: A. E. Kelly, K. Y. Kuo, B. Marlow, and A. Tiberghien

Copyright (@ 2013 Jürgen Drissner et al. This is an open access article distributed under the Creative Commons Attribution License, which permits unrestricted use, distribution, and reproduction in any medium, provided the original work is properly cited.

The "Green Classroom" in the Botanical Garden of the University of Ulm is a learning forum outside school. Its educational concept is based on experiential learning and is geared towards expanding students' biological knowledge and developing positive attitudes towards small animals such as invertebrates. In the first study, we assessed attitudes towards small animals of 43 students before and after they visited the "Green Classroom", and we compared the answers they gave in their questionnaires with those of 46 students from a control group. Although the students spent only one morning in the "Green Classroom", some of their attitudes improved after their visit. In the second study, 102 secondary-school students (56 who had previously visited the "Green Classroom") were asked to write an essay about small animals. Students who had visited the "Green Classroom" before portrayed more positive emotions towards small animals and showed more biological understanding than their peers.

\section{Introduction}

Sustainable development is seen as the key to securing decent living conditions for future generations. Ecological, economical, and cultural aspects must be considered globally. Every person and every institution is encouraged to make a contribution towards sustainable development. Educational institutions obviously play a major role in this endeavour. The basic educational aspects for sustainable development for the German school system are already mapped out [1]. This German concept offers a guideline for content, learning methods, and didactics of a modern environmental education. The concept calls for hands-on experiential learning through direct contact with animals in their environment, the involvement of emotions, and the aim to shape values in a holistic approach. Normally, experiential learning such as excursions and programmes like the "Green Classroom" are suggested as means for a modern environmental education.

In addition to the German concept [1], Palmer [2] acknowledges that prior knowledge and experiences, which are crucial for subsequent learning, differ (to varying extent) from one student to the next. "Research has demonstrated that these formative influences may indeed be more significant than planned formal educational programs in the development of environmental understanding and concern, and, wherever possible, educators need to be aware of prior knowledge and build upon it in a meaningful way," [2].

What do children already know about animals? When asked to list the species they know, children generally talk about animals that are not found in their own environment [3]. Vertebrates which seem to be more remarkable and extraordinary are mentioned whereas small animals (invertebrates and insects) are hardly ever discussed $[4,5]$. Worse still, the small animals that do get mentioned are associated with feelings of disgust and abhorrence. These negative emotions towards small animals pose a genuine obstacle for an effective ecological education [6] or education in sustainable development. It should be noted that the majority of these invertebrates are harmless and that invertebrates are essential for our ecological system. Moreover, many of them are classed as endangered species or on the brink of extinction [6-8]. Moreover, if children are not familiar with 
the animals they encounter in their own natural environment, they will find it difficult to address issues of biodiversity and ecological problems $[9,10]$. The extinction of species has been dramatically accelerating, and it is difficult to predict the outcome [11]. There is an obvious need for an educational programme that raises interest in and instils awareness of invertebrates, eradicating any negative emotions such as disgust along the way.

What would the learning process entail in an educational programme that wants to address knowledge, emotions, and attitudes, and that needs to raise awareness of invertebrates at the same time? Opinions about the relationship between knowledge on the one hand and environmental attitudes and ecological awareness on the other hand vary considerably. However, many researchers assume that an important positive relationship actually exists [12-15]. The rationale behind this assumption is that "we can only protect what we know". Furthermore, we can only miss a species if we have had some kind of attachment to it $[9,16,17]$. Precise knowledge about the biology and ecology of living creatures is especially important in order to create an emotional bond with plants and animals as well as to foster appreciation for the environment [18].

Studying nature outside the classroom is the most effective and, at the same time, the most pleasurable way to teach children about various species and biodiversity. This approach should, in fact, be adopted more often [19]. Several scientists also emphasise the relevance of the active process in learning about diversity in natural habitats [18, 20, 21]. Furthermore, biology lessons can be made more enjoyable by studying living plants and animals first-hand [22, 23]. Direct contact with nature helps to enhance ecological awareness, positive environmental attitudes, and a caring approach towards living creatures $[16,22,24,25]$. Winkel, a pioneer of environmental education, emphasised the importance of an emotional encounter with living creatures to promote environmental ethics even before the importance of sustainable development was discussed. He stated that the behaviour of human beings was only partially determined by knowledge, and that values, conscience, and morale played an equally important role. While values and feelings cannot develop without knowledge, taking or avoiding action, caring for something, and adopting a gentle approach are inspired by feelings that come from within-from the heart, so to speak [26].

With the above mentioned ideas in mind, learning in the "Green Classroom" is organised in such a way that students encounter animals in their natural habitat, and what they observe will be explained and put into context. Questions that arise from these encounters will be addressed immediately. The topics that students deal with in the "Green Classroom" are topics about small animals that can be found in the environment of the children. The Botanical Garden allows students to explore the animals in their original habitat, for example, meadow, forest, and lake. Students receive an instruction about the habitat and its importance as well as about how to deal respectfully with the animals that live there. After that students explore the habitat and carefully catch animals in special small boxes. These boxes will be taken to the "Green Classroom" that is integrated in all of the habitats listed above. There the animals will be observed through magnifying glasses. While working with the small animals, scientific facts are presented in order to introduce specific invertebrates and possibly initiate "personal relationships". Students will be asked to produce, depending on their age, drawings of animals themselves or of their food chains and habitats. Observations in the "Green Classroom" show that students begin to empathise and care for these animals in this process. For further information, see (http://www.uni-ulm.de/einrichtungen/garten/gruenesklassenzimmer.html).

Some of the goals of the "Green Classroom" (e.g., to expand knowledge of especially small animals such as invertebrates and insects and to improve emotions and attitudes towards small animals in our own environment) were evaluated in this study.

\section{Study 1}

\subsection{Methods}

\subsubsection{Participants and Design}

Participants. The sample comprised 89 school students (grade $6)$. Forty three students formed the intervention group and visited the "Green Classroom" for one morning. Forty six students from the parallel classes (same school, same grade) served as control group.

Measures. Attitudes towards small animals such as beetles, wood lice, centipedes, or spiders were recorded with the help of a semantic differential. Students were asked to choose where their position lies on a scale between two bipolar adjectives (e.g., "Boring-Fascinating", "Useless-Valuable", or "Disgusting-Cute"). Altogether students marked their choice for 13 bipolar adjective pairs that focused on the perceived value of animals and the emotions towards them (e.g., fear and disgust).

Procedure. Students of the intervention group completed the questionnaire to obtain a baseline level of their attitudes between 5 and 7 days before their visit to the "Green Classroom". Students of the control group completed the identical questionnaire at the same time. The classes of the intervention group visited the "Green Classroom" in the Botanical Garden from 9 am to $12 \mathrm{pm}$ on their assigned day. Back in school, over the next 5 to 7 days, students in both the intervention as well as the control group completed the questionnaires for the second time as a followup measure.

2.2. Results. A Wilcoxon test for paired samples was used to analyse the development of the groups (see Table 1). The intervention group showed a significant improvement on nine of the 13 bipolar adjective pairs. After the visit of the "Green Classroom", these students rated the small animals more fascinating and valuable, cuter, more interesting and necessary, better, cooler, more harmless, and more precious than before. The students in the control group also changed 
TABLE 1: Means for pre- and posttest of attitudes towards small animals for intervention and control groups. Statistical significance of differences was computed by the nonparametric Wilcoxon test for paired samples.

\begin{tabular}{|c|c|c|c|c|c|c|c|c|c|}
\hline & & & Aterventic & oup $(N=$ & & & Control g & $(N=46$ & \\
\hline & & $M$ pre & $M$ post & $Z$-value & $P$-level & $M$ pre & $M$ post & $Z$-value & $P$-level \\
\hline Boring & Fascinating & 4,11 & 5,14 & 3,76 & $0,000^{* * *}$ & 4,04 & 4,02 & 0,46 & 0,649 \\
\hline Dangerous & Safe & 5,23 & 5,52 & 1,71 & 0,086 & 5,07 & 5,23 & 0,40 & 0,690 \\
\hline Useless & Valuable & 4,34 & 5,14 & 2,51 & $0,012^{*}$ & 4,07 & 4,30 & 0,90 & 0,368 \\
\hline Disgusting & Cute & 3,30 & 3,82 & 2,48 & $0,013^{*}$ & 3,22 & 3,26 & 0,89 & 0,376 \\
\hline Uninteresting & Interesting & 4,73 & 5,45 & 2,72 & $0,006^{* *}$ & 4,48 & 4,13 & 1,21 & 0,226 \\
\hline Unnecessary & Necessary & 4,61 & 5,20 & 2,58 & $0,010^{* *}$ & 4,48 & 4,19 & 1,37 & 0,170 \\
\hline Bad & Good & 4,45 & 5,48 & 3,24 & $0,001^{* *}$ & 4,50 & 4,28 & 0,84 & 0,399 \\
\hline Morbid & Natural & 6,05 & 6,27 & 1,29 & 0,198 & 5,70 & 5,57 & 0,58 & 0,563 \\
\hline Repulsive & Appealing & 4,68 & 4,95 & 1,12 & 0,265 & 4,33 & 4,28 & 0,27 & 0,790 \\
\hline Uncool & Cool & 4,32 & 5,00 & 2,88 & $0,004^{* *}$ & 4,20 & 3,85 & 1,99 & $0,046^{*}$ \\
\hline Dull & Funny & 4,70 & 4,86 & 0,65 & 0,517 & 4,22 & 4,28 & 0,32 & 0,746 \\
\hline Weird & Harmless & 4,66 & 5,32 & 2,77 & $0,006^{* *}$ & 5,11 & 5,02 & 0,56 & 0,572 \\
\hline Worthless & Precious & 5,23 & 6,05 & 2,52 & $0,012^{*}$ & 4,43 & 4,66 & 1,16 & 0,246 \\
\hline
\end{tabular}

${ }^{*} P<0,05 ;{ }^{* *} P<0,01 ;{ }^{* * *} P<0,001$.

TABLE 2: Means for pre- and posttest of attitudes towards small animals for intervention and control groups (boys). Statistical significance of differences was computed by the nonparametric Wilcoxon test for paired samples.

\begin{tabular}{|c|c|c|c|c|c|c|c|c|c|}
\hline & & \multicolumn{4}{|c|}{ Intervention group: boys $(N=26)$} & \multicolumn{4}{|c|}{ Control group: boys $(N=34)$} \\
\hline & & $M$ pre & $M$ post & $Z$-value & $P$-level & $M$ pre & $M$ post & $Z$-value & $P$-level \\
\hline Boring & Fascinating & 4,23 & 5,08 & 2,31 & $0,021^{*}$ & 4,09 & 4,18 & 0,04 & 0,970 \\
\hline Dangerous & Safe & 5,23 & 5,35 & 0,97 & 0,334 & 4,97 & 5,35 & 0,95 & 0,341 \\
\hline Useless & Valuable & 4,38 & 5,00 & 1,06 & 0,289 & 4,21 & 4,47 & 0,81 & 0,420 \\
\hline Disgusting & Cute & 3,46 & 3,85 & 1,91 & 0,555 & 3,55 & 3,59 & 0,97 & 0,332 \\
\hline Uninteresting & Interesting & 5,04 & 5,50 & 0,94 & 0,351 & 4,82 & 4,38 & 1,36 & 0,175 \\
\hline Unnecessary & Necessary & 4,92 & 5,08 & 0,59 & 0,556 & 4,82 & 4,41 & 1,65 & 0,100 \\
\hline Bad & Good & 4,54 & 5,62 & 2,40 & $0,016^{*}$ & 4,61 & 4,35 & 0,80 & 0,426 \\
\hline Morbid & Natural & 5,85 & 6,15 & 1,56 & 0,120 & 5,58 & 5,56 & 0,04 & 0,965 \\
\hline Repulsive & Appealing & 4,96 & 5,04 & 0,34 & 0,733 & 4,39 & 4,35 & 0,24 & 0,808 \\
\hline Uncool & Cool & 4,38 & 5,19 & 2,32 & $0,020^{*}$ & 4,27 & 3,97 & 1,46 & 0,145 \\
\hline Dull & Funny & 4,77 & 4,88 & 0,33 & 0,740 & 4,33 & 4,32 & 0,02 & 0,986 \\
\hline Weird & Harmless & 4,73 & 5,38 & 2,30 & $0,022^{*}$ & 5,24 & 5,26 & 0,10 & 0,920 \\
\hline Worthless & Precious & 5,50 & 6,00 & 1,04 & 0,300 & 4,58 & 4,91 & 1,39 & 0,165 \\
\hline
\end{tabular}

${ }^{*} P<0,05 ;{ }^{* *} P<0,01 ;{ }^{* * *} P<0,001$.

one rating: they rated the small animals at the second time of inquiring as "uncooler" than at the first time. The results are presented in Table 1.

The study showed gender-specific differences (results are presented in Tables 2 and 3). After the intervention, the boys rated the small animals more fascinating and harmless as well as better and cooler; the girls of the intervention group rated these animals better, more fascinating, more valuable, more interesting, more necessary, and more precious than before.

\section{Study 2}

\subsection{Methods}

3.1.1. Participants and Design. One hundred and two secondary students (grade 6), 56 who had visited the "Green
Classroom" before (intervention group), were asked to write an essay about small animals such as insects and other invertebrates. The students of the test group visited the "Green Classroom" up to one year before (min. 2, max. 12 months). Classes consisted of intervention group students as well as students who had never visited the "Green Classroom" before; that is, intervention group and control group learned in the same school with the same teacher.

The written essays were evaluated in terms of the following aspects:

(1) number of scientifically correct statements: for example, small animals are an important part of the food chain,

(2) number of misconceptions (scientific incorrect statements): for example, the ladybug shows its age by the number of spots on its back, 
TABLE 3: Means for pre- and posttest of attitudes towards small animals for intervention and control groups (girls). Statistical significance of differences was computed by the nonparametric Wilcoxon test for paired samples.

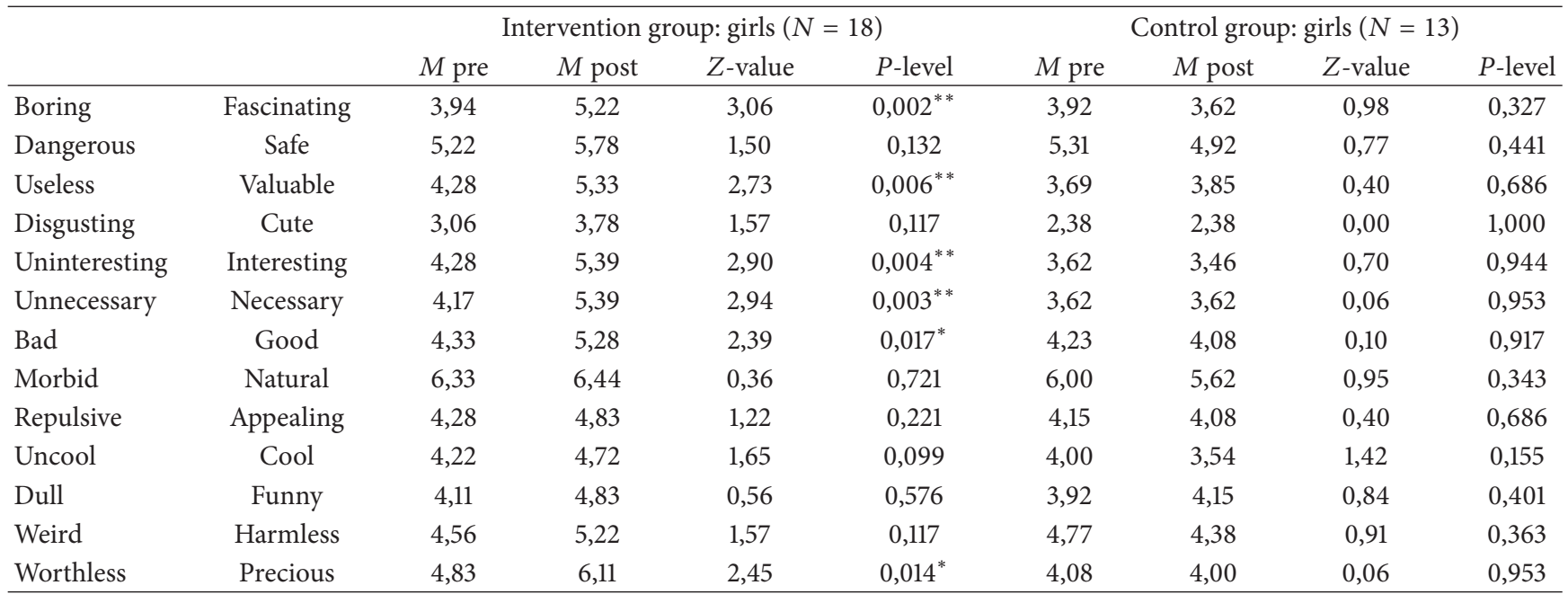

${ }^{*} P<0,05 ;{ }^{* *} P<0,01 ;{ }^{* * *} P<0,001$.

TABLE 4: Knowledge of and attitude towards small animals. Means for the intervention group and the control group (Mann-Whitney $U$ test): $N_{\text {test group }}=56 ; N_{\text {control group }}=46$.

\begin{tabular}{|c|c|c|c|c|}
\hline & Intervention $M$ & Control $M$ & $Z$-value & $P$-level \\
\hline Scientifically correct statements & 9,14 & 8,80 & 0,76 & 0,448 \\
\hline Misconceptions & 0,55 & 1,50 & $-3,98$ & $0,000^{* * *}$ \\
\hline Knowledge & 8,59 & 7,11 & 1,82 & $0,068^{(*)}$ \\
\hline Positive Emotions & 0,59 & 0,17 & 2,77 & $0,006^{* *}$ \\
\hline Negative Emotions & 0,27 & 0,54 & $-0,11$ & 0,911 \\
\hline Emotions & 0,32 & $-0,37$ & 3,04 & $0,002^{* *}$ \\
\hline
\end{tabular}

${ }^{*} P<0,05 ;{ }^{* *} P<0,01 ;{ }^{* * *} P<0,001$.

Knowledge: difference between correct and incorrect statements.

Emotions: difference between positive and negative emotions.

(3) number of positive emotions: for example, spiders are peaceful creatures,

(4) number of negative emotions: for example, small animals are disgusting and annoying.

3.2. Results. The students who did not visit the "Green Classroom" wrote more scientifically incorrect statements (misconceptions) than the intervention group, whereas the students of the intervention group showed more positive emotions towards small animals (insects and other invertebrates). Detailed results are presented in Table 4.

The study also showed gender-specific differences. The boys of the control group wrote more scientifically incorrect statements (misconceptions), whereas the test group showed a better knowledge (difference between correct and incorrect statements) of the small animals. Detailed results are presented in Table 5 .

The girls of the test group showed more positive emotions towards these animals. Detailed results are presented in Table 6.

\section{Discussion and Conclusion}

The children who attended the "Green Classroom" displayed in an essay about small animals fewer misconceptions and more positive emotions towards them.

This may not be a big deal, but it does matter. Small animals are crucial for our ecosystem. Yet, many of them are endangered species. Small animals receive little attention from media in comparison to birds or large vertebrates. Therefore, children are more aware of birds and large vertebrates. But if children are not even aware of small animals, then how can they be protected by future generations? Against this background, many authors [3-6, 8, 27] argue for improving the attitudes and emotions towards as well as the knowledge of small animals. For example, Snaddon and Turner [27] call for efforts to emphasise small animals and their significance.

An educational programme that helps to improve the attitudes towards small animals is very important in light of the increasingly smaller number of children valuing the animals in their environment, despite the fact that they are ecologically extremely important $[5,8,19,27]$. 
TABLE 5: Knowledge of and attitude towards small animals. Means for the intervention group and the control group (boys, Mann-Whitney $U$ test): $N_{\text {test group }}=31, N_{\text {control group }}=33$.

\begin{tabular}{|c|c|c|c|c|}
\hline Boys & Intervention $M$ & Control $M$ & $Z$-value & $P$-level \\
\hline Scientifically correct statements & 9,39 & 8,09 & 1,11 & 0,269 \\
\hline Misconceptions & 0,54 & 1,52 & $-3,44$ & $0,001^{* * *}$ \\
\hline Knowledge & 8,84 & 6,58 & 2,03 & $0,042^{*}$ \\
\hline Positive Emotions & 0,48 & 0,24 & 0,84 & 0,404 \\
\hline Negative Emotions & 0,23 & 0,73 & $-0,71$ & 0,477 \\
\hline Emotions & 0,26 & $-0,48$ & 1,80 & 0,072 \\
\hline
\end{tabular}

${ }^{*} P<0,05 ;{ }^{* *} P<0,01 ;{ }^{* * *} P<0,001$.

Knowledge: difference between correct and incorrect statements.

Emotions: difference between positive and negative emotions.

TABLE 6: Knowledge of and attitude towards small animals. Means for the intervention group and the control group (girls, Mann-Whitney $U$ test): $N_{\text {test group }}=25, N_{\text {control group }}=13$.

\begin{tabular}{lcccc}
\hline Girls & Intervention $M$ & Control $M$ & $Z$-value & $P$-level \\
\hline Scientifically correct statements & 8,84 & 10,62 & $-0,51$ & 0,610 \\
Misconceptions & 0,56 & 1,46 & $-1,74$ & 0,821 \\
Knowledge & 8,28 & 8,46 & 0,00 & 1,000 \\
Positive Emotions & 0,72 & 0,00 & 3,10 & $0,002^{* *}$ \\
Negative Emotions & 0,32 & 0,08 & 1,02 & 0,308 \\
Emotions & 0,40 & $-0,08$ & 2,66 & $0,008^{* *}$ \\
\hline
\end{tabular}

${ }^{*} P<0,05 ;{ }^{* *} P<0,01 ;{ }^{* * *} P<0,001$.

Knowledge: difference between correct and incorrect statements.

Emotions: difference between positive and negative emotions.

These results support a previous study with older students about the same intervention: Drissner et al. [28] could show in a similar study that differences in knowledge and emotions of students who did or did not visit the "Green Classroom" could be found years after the visit. In that study, the essays of 119 secondary students (76 who had previously visited the "Green Classroom") were evaluated using the same criteria as in the present study. The students who had visited the "Green Classroom" demonstrated better knowledge of and more positive emotions towards the animals, even though it had been five years since the visit for some of the students.

The intrinsic motivation of students to interact with small animals and to find them fascinating could provide a sound basis for generating further interest in fauna. It could be presumed that contact with the small animals encountered in the "Green Classroom" environment triggers students' interest and approach towards small animals, subsequently establishing a more positive attitude towards these animals. This rise of intrinsic motivation, shown by Drissner et al. [29], could help explain the positive changes found in the intervention group that showed a significant improvement on nine of the 13 bipolar adjective pairs: more fascinating and valuable, cuter, more interesting and necessary, better, cooler, more harmless, and more precious. The students who visited the "Green Classroom" later reported that they enjoyed learning about small animals more than before.

The positive results (e.g., better attitudes and emotions towards small animals) noted in the intervention group but not in the control group are remarkable considering the duration of the visit. The students only attended the "Green Classroom" for half a day. This is extremely short-term participation. According to other studies conducted to date, short-term participation takes at least a few days, possibly even weeks, in order to have any impact (see, e.g., $[12,25,30]$ ); this is a considerably longer time length by comparison. So far, it has been assumed that environmental programmes aiming to change attitudes need to be continued for at least several days. It has been recommended that programmes of several days' duration be initiated in order to effectively change environmental attitudes [12]. The fact that some positive changes have been recorded from a half-day teaching programme could reflect the importance of the educational work in a learning forum outside school. Half-day teaching programmes are an important part of experiential learning outside the classroom. Such short programmes can be easily integrated into the curricula, and they can be prepared for and reflected on accordingly by the students within the classroom setting. In Germany, it is rather unlikely that schools and teachers can find the time to spend more than one half-day outside the classroom investigating just one phenomenon. For these reasons, it was interesting to see whether a programme of such short duration has any impact on the knowledge and opinions of the students.

The results of both studies taken together suggest that the outdoor setting of an educational programme can have a valuable formative influence, helping to develop opinions 
and emotions towards specific animals that could lead to a stronger long-term knowledge and a more positive attitude towards these animals and their importance.

\section{Acknowledgments}

The authors are especially grateful to Marian Kazda, the Director of the Botanical Garden of the University of Ulm, for his kind support. The authors also wish to extend their thanks to the teachers and students who took part in the evaluation.

\section{References}

[1] Bund-Länder-Kommission für Bildungsplanung und Forschungsförderung [BLK], Bildung für eine nachhaltige Entwicklung-Orientierungsrahmen, vol. 69, BLK, Bonn, Germany, 1998.

[2] J. Palmer, A.Environmental Education in the 21st Century: Theory, Practice, Progress and Promise, Routledge, London, UK, 1998.

[3] R. Lock, "Biology and the environment-a changing perspective? Or "there's wolves in them there woods!'”, Journal of Biological Education, vol. 29, pp. 3-4, 1995.

[4] S. R. Kellert, "Values and perceptions of invertebrates," Conservation Biology, vol. 7, no. 4, pp. 845-855, 1993.

[5] J. L. Snaddon, E. C. Turner, and W. A. Foster, "Children's perceptions of rainforest biodiversity: which animals have the lion's share of environmental awareness?" PLOS ONE, vol. 3, no. 7, Article ID e2579, 2008.

[6] R. D. Bixler, M. F. Floyd, and F. Myron, "Hands on or hands off? Disgust sensitivity and preference for Environmental Education activities," The Journal of Environmental Education, vol. 30, pp. 4-11, 1999.

[7] E. Wilson, "Little things that run the world," Conservation Biology, vol. 1, pp. 344-346, 1987.

[8] R. Wagler and A. Wagler, "Arthropods: attitude and incorporation in preservice elementary teachers," International Journal of Environmental \& Science Education, vol. 6, no. 3, pp. 229-250, 2011.

[9] M. Weilbacher, "The renaissance of the naturalist," The Journal of Environmental Education, vol. 25, pp. 4-7, 1993.

[10] V. H. Heywood, Global Biodiversity Assessment, Cambridge University Press, Cambridge, UK, 1995.

[11] J. Rockström, W. Steffen, K. Noone et al., "A safe operating space for humanity," Nature, vol. 461, no. 7263, pp. 472-475, 2009.

[12] F. Bogner, "The influence of short-term outdoor ecology education on long-term variables of environmental perspective," The Journal of Environmental Education, vol. 29, pp. 17-29, 1998.

[13] F. G. Kaiser, S. Wölfing, and U. Fuhrer, "Environmental attitude and ecological behaviour," Journal of Environmental Psychology, vol. 19, no. 1, pp. 1-19, 1999.

[14] L. Barraza and R. A. Walford, "Environmental Education: a comparison between English and Mexican school children," Environmental Education Research, vol. 8, pp. 171-186, 2002.

[15] C. M. DiEnno and S. C. Hilton, "High school students' knowledge, attitudes, and levels of enjoyment of an Environmental Education unit on nonnative plants," The Journal of Environmental Education, vol. 37, no. 1, pp. 13-25, 2005.

[16] L. Fawcett, "Children's wild animal stories: questioning interspecies bonds," Canadian Journal of Environmental Education, vol. 7, no. 2, pp. 125-139, 2002.
[17] P. Lindemann-Matthies, "The influence of an educational programme on children's perception of biodiversity," The Journal of Environmental Education, vol. 33, pp. 22-31, 2002.

[18] J. Mayer, "Bedeutung der Formenkunde für die Umweltbildung," Verhandlungen der Gesellschaft für Ökologie, vol. 22, pp. 379-384, 1993.

[19] P. Lindemann-Matthies, "Investigating nature on the way to school: responses to an educational programme by teachers and their pupils," International Journal of Science Education, vol. 28, no. 8, pp. 895-918, 2006.

[20] L. Chawla, "Significant life experiences revisited: a review of research on sources of Environmental Sensitivity," The Journal of Environmental Education, vol. 29, pp. 11-23, 1998.

[21] G. de Haan, "Vorwort," in Kinder lernen Umwelt schützen: Handbuch für Umweltpädagogik in Kindergarten und Grundschule, J. Kandeler, Ed., Natur und Umwelt, Berlin, Germany, 2005.

[22] R. Lock, "Fieldwork in the life sciences," International Journal of Science Education, vol. 20, no. 6, pp. 633-642, 1998.

[23] S. Barker, D. Slingsby, and S. Tilling, "Ecological fieldwork: is there a problem?" Environmental Education, vol. 71, pp. 9-10, 2002.

[24] L. B. Yore and S. Boyer, "College students' attitudes towards living organisms: the influence of experience \& knowledge," American Biology Teacher, vol. 59, no. 9, pp. 558-563, 1997.

[25] H.-M. Haase, Worldrangers: Ein pädagogischer Beitrag für eine nachhaltige Entwicklung. Hintergründe und Praxisvorschläge für eine zeitgemäße Umweltbildung, Dr. Kovac, Hamburg, Germany, 2003.

[26] G. Winkel, Umwelt und Bildung: Denk- und Praxisanregungen für eine ganzheitliche Natur- und Umwelterziehung, Kallmeyersche Verlagsbuchhandlung, Seelze, Germany, 1995.

[27] J. L. Snaddon and E. C. Turner, "A child's eye view of the insect world: perceptions of insect diversity," Environmental Conservation, vol. 34, no. 1, pp. 33-35, 2007.

[28] J. Drissner, K. Hille, S. Debatin, and H.-M. Haase, "Das Grüne Klassenzimmer im Botanischen Garten der Universität Ulm-eine Wirkungsanalyse," Diskurs Kindheits- und Jugendforschung, vol. 2, pp. 209-218, 2008.

[29] J. Drissner, H.-M. Haase, and K. Hille, "Short-term Environmental Education-does it work? An evaluation of the "Green Classroom'”' Journal of Biological Education, vol. 44, no. 4, pp. 149-155, 2010.

[30] B. E. Rideout, "The effect of a brief environmental problems module on endorsement of the new ecological paradigm in college students," The Journal of Environmental Education, vol. 37, no. 1, pp. 3-11, 2005. 

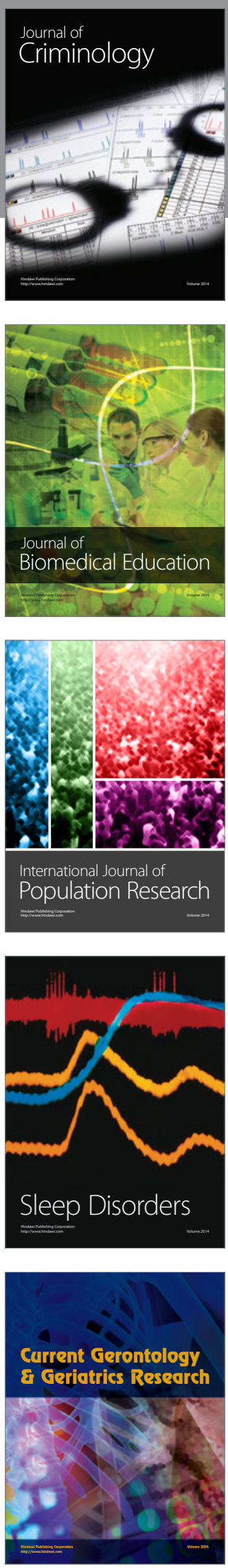
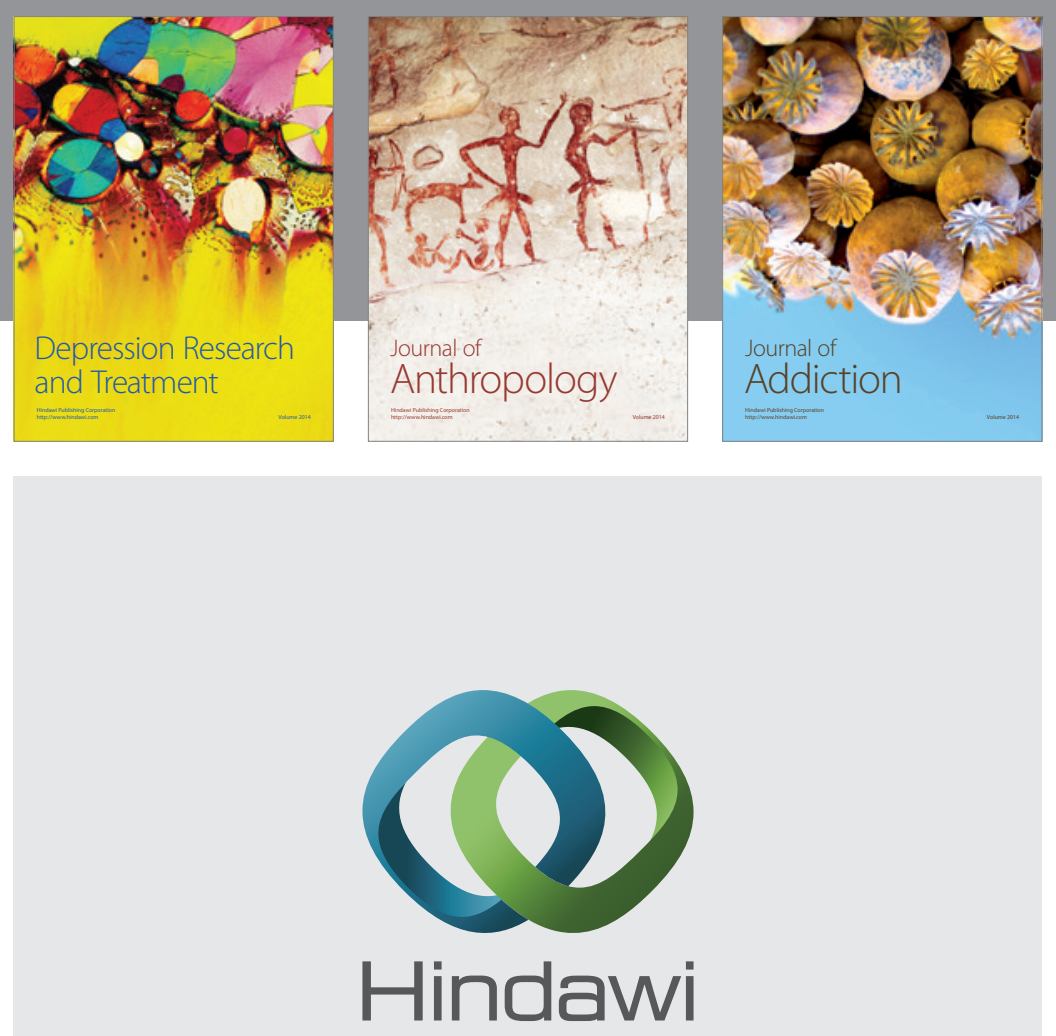

Submit your manuscripts at

http://www.hindawi.com

Child Development Research
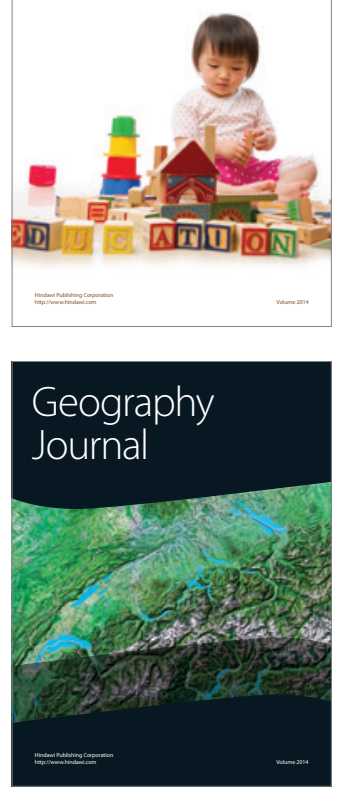

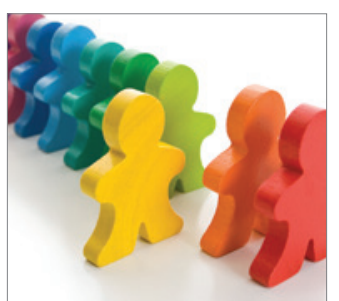

Autism

Research and Treatment
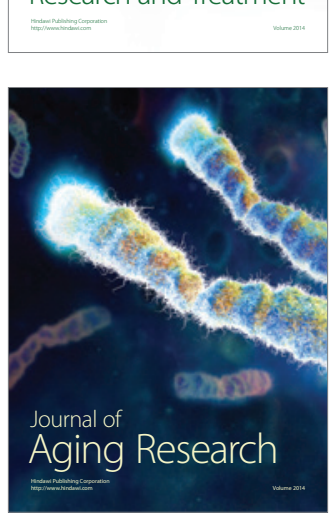
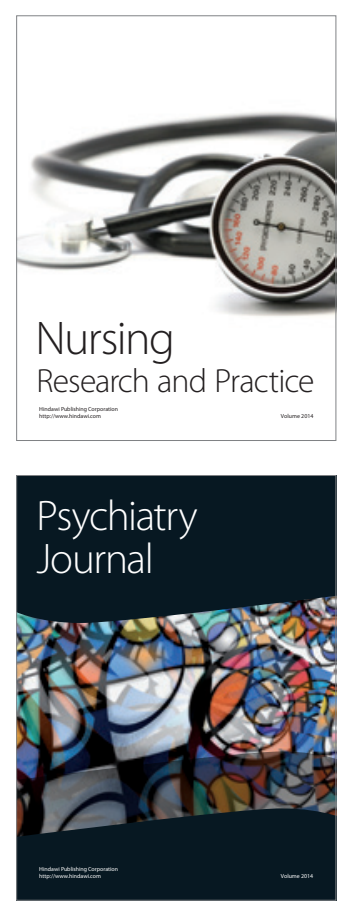
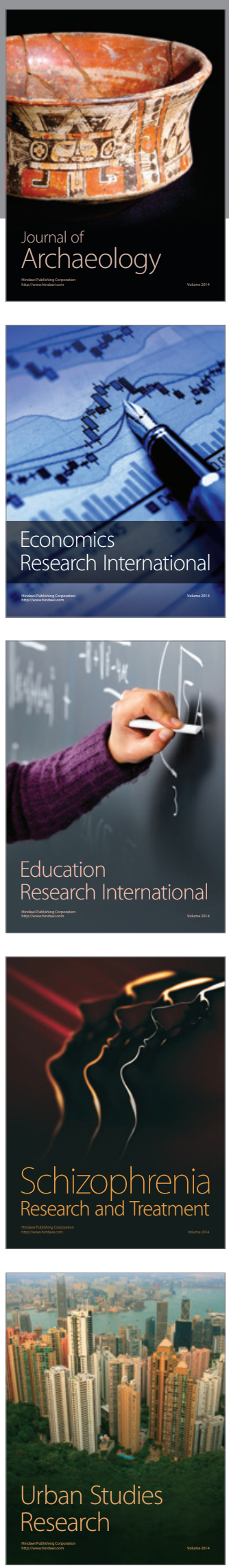